\title{
Probiotics and the Prevention of Necrotizing Enterocolitis
}

\author{
Christian P. Braegger \\ Division of Gastroenterology and Nutrition, University Children's Hospital, Zürich, Switzerland
}

Necrotizing enterocolitis is one of the most serious gastrointestinal emergencies in the neonatal intensivecare unit [1]. It predominantly affects preterm infants. The onset of disease is usually between the 3rd and the 10th day of life. Necrotizing enterocolitis presents with a wide spectrum of clinical symptoms, ranging from nonspecific gastrointestinal disturbance to a fulminant course of intestinal gangrene and perforation. Typical early signs are abdominal distension, delayed gastric emptying, diarrhea, abdominal tenderness and gastrointestinal bleeding. Characteristically, extensive hemorrhagic inflammatory necrosis of the terminal ileum and ascending colon can be found. In severe cases the entire bowel may be involved. Intramural hemorrhage, gangrene, peritonitis and edema may progress to intestinal necrosis with extensive infiltration of neutrophil leukocytes.

Risk factors include prematurity, hypoxia, formula feeding, bacterial infection and intestinal ischemia $[2,3]$. Mortality is high (15-30\%) and related to the presence of bacteremia, disseminated intravascular coagulation, ascites and very low birth weight. Etiology and pathogenesis of necrotizing enterocolitis remain unknown. However, formula feeding, intestinal mucosal barrier dysfunction and dysbalance of bacterial colonization may be contributing factors, leading to an inappropriate inflam- matory response of the immature intestinal immune system, resulting in rapidly evolving intestinal gangrene, perforation, sepsis, shock and death $[1,2,4]$.

Probiotics have been shown to be able to modify both the intestinal microbiota as well as the intestinal immune response. On this background, several clinical trials have been carried out in order to investigate the potential role of probiotics in the prevention of necrotizing enterocolitis [5-13]. Most of these studies, among them many randomized controlled trials, suggest a significant benefit of probiotics in the prevention of necrotizing enterocolitis, confirming previous observations in experimental animal models $[14,15]$. Possible mechanisms of probiotics in the prevention of necrotizing enterocolitis are beneficial modification of the intestinal microbiota, strengthening of the intestinal mucosal barrier and attenuating the intestinal immune response to bacteria and bacterial products.

The results of the randomized controlled trials have been analyzed in several comments and reviews [16-19]. There is a general agreement that probiotic supplementation has a great potential to significantly reduce the risk of necrotizing enterocolitis and the overall mortality in premature infants with very low birth weight. However, there is obviously great variability of the clinical trials reported, with respect to inclusion criteria of the patients,

\section{KARGER}

Fax +4161306 1234

E-Mail karger@karger.ch

www.karger.com
(C) 2010 S. Karger AG, Basel

0250-6807/10/0575-0014\$26.00/0

Accessible online at:

www.karger.com/anm
Christian P. Braegger, MD

Division of Gastroenterology and Nutrition

University Children's Hospital, Steinwiesstrasse 75

$\mathrm{CH}-8032$ Zürich (Switzerland)

Tel. +41 44266 7223, Fax +41 44266 7830, E-Mail christian.braegger@kispi.uzh.ch 
type and dose of probiotics used, duration of treatment and feeding regimens.

A further concern is safety. Although sepsis caused by probiotics was not observed in any of the randomized controlled trials on the prevention of necrotizing enterocolitis, there are rare case reports of systemic infections caused by probiotic bacteria in children with underlying diseases [20-23]. The long-term safety of probiotic bacteria in terms of permanent alteration in the intestinal bacterial colonization should also be studied.

In conclusion, probiotics appear to be safe and effective in preventing necrotizing enterocolitis in very low birth weight infants. There is increasing evidence that supplementation with probiotics may reduce both the risk of necrotizing enterocolitis as well as mortality in preterm infants. However, there is great heterogeneity among the published clinical trials and therefore insufficient information to make sound recommendations for the type of organism, dose and timing that should be used for probiotic supplementation in very low birth weight infants. Therefore, further large well-designed multicenter trials are urgently needed before the use of probiotics in preterm infants may become routine in all neonatal intensive-care units.

\section{Disclosure Statement}

C.P.B. has been an advisory board member for Danone.

\section{References}

1 Lin PW, Stoll BJ: Necrotising enterocolitis. Lancet 2006;368:1271-1283.

$\checkmark 2$ Lin PW, Nasr TR, Stoll BJ: Necrotizing enterocolitis: recent scientific advances in pathophysiology and prevention. Semin Perinatol 2008;32:70-82.

3 Lucas A, Cole TJ: Breast milk and neonatal necrotizing enterocolitis. Lancet 1990;336: 1519-1523.

4 Pender SL, Braegger C, Gunther U, Monteleone G, Meuli M, Schuppan D, Macdonald TT: Matrix metalloproteinases in necrotising enterocolitis. Pediatr Res 2003;54:160164.

5 Kitajima H, Sumida Y, Tanaka R, Yuki N, Takayama H, Fujimura M: Early administration of Bifidobacterium breve to preterm infants: randomised controlled trial. Arch Dis Child Fetal Neonatal Ed 1997;76:F101-F107.

6 Hoyos AB: Reduced incidence of necrotising enterocolitis associated with enteral administration of Lactobacillus acidophilus and Bifidobacterium infantis to neonates in an intensive care unit. Int J Infect Dis 1999;3: 197-202.

7 Dani C, Biadaioli R, Bertini G, Martelli E, Rubaltelli FF: Probiotics feeding in prevention of urinary tract infection, bacterial sepsis and necrotizing enterocolitis in preterm infants. Biol Neonate 2002;82:103-108.

8 Costalos C, Skouteri V, Gounaris A, Sevastiadou S, Triandafilidou A, Ekonomidou C, Kontaxaki F, Petrochilou V: Enteral feeding of premature infants with Saccharomyces boulardii. Early Hum Dev 2003;74:89-96. $\checkmark 9$ Bin-Nun A, Bromiker R, Wilschanski M, Rudensky B, Caplan M, Hammerman C: Oral probiotics prevent necrotizing enterocolitis in very low birth weight neonates. J Pediatr 2005; 147:192-196.

$\checkmark 10$ Lin HC, Su BH, Chen AC, Lin TW, Tsai CH, Yeh TF, Oh W: Oral probiotics reduce the incidence and severity of necrotizing enterocolitis in very low birth weight infants. Pediatrics 2005;115:1-4.

11 Manzoni P, Mostert M, Leonessa ML, Priolo C, Farina D, Monetti C, Latino MA, Gomirato G: Oral supplementation with Lactobacillus casei subspecies rhamnosus prevents enteric colonization by Candida species in preterm neonates: a randomized study. Clin Infect Dis 2006;15:1735-1742.

12 Mohan R, Koebnick C, Schildt J, Schmidt S, Mueller M, Possner M, Radke M, Blaut M: Effects of Bifidobacterium lactis Bb12 supplementation on intestinal microbiota of preterm neonates: a double placebo controlled, randomised study. J Clin Microbiol 2006;44:4025-4031.

$\checkmark 13$ Lin HC, Hsu CH, Chen HL, Chung MY, Hsu JF, Lien RI, Tsao LY, Chen CH, Su BH: Oral probiotics prevent necrotizing enterocolitis in very low birth weight preterm infants: a multicenter, randomized, controlled trial. Pediatrics 2008;122;693-700.

14 Caplan MS, Miller-Catchpole R, Kaup S, Russell T, Lickerman M, Amer M, Xiao Y, Thomson RJ: Bifidobacterial supplementation reduces the incidence of necrotizing enterocolitis in a neonatal rat model. Gastroenterology 1999;117:577-583.

15 Butel MJ, Waligora-Dupriet AJ, Szylit O: Oligofructose and experimental model of neonatal necrotising enterocolitis. Br J Nutr 2002;87:S213-S219.
16 Stricker T, Braegger CP: Oral probiotics prevent necrotizing enterocolitis. J Pediatr Gastroenterol Nutr 2006;42:446-447.

17 Deshpande G, Rao S, Patole S: Probiotics for prevention of necrotising enterocolitis in preterm neonates with very low birth weight: a systematic review of randomised controlled trials. Lancet 2007;369:1614-1620.

18 Barclay AR, Stenson B, Simpson JH, Weaver LT, Wilson DC: Probiotics for necrotizing enterocolitis: a systematic review. J Pediatr Gastroenterol Nutr 2007;45:569-576.

19 Alfaleh K, Bassler D: Probiotics for prevention of necrotizing enterocolitis in preterm infants. Cochrane Database Syst Rev 2008:CD005496.

20 Salminen MK, Rautelin H, Tynkkynen S, Poussa T, Saxelin M, Valtonen V, Järvinen A: Lactobacillus bacteremia, clinical significance, and patient outcome, with special focus on probiotic L. rhamnosus GG. Clin Infect Dis 2004;38:62-69.

21 De Groote MA, Frank DN, Dowell E, Glode MP, Pace NR: Lactobacillus rhamnosus GG bacteremia associated with probiotic use in a child with short gut syndrome. Pediatr Infect Dis J 2005;24:278-280.

22 Kunz AN, Noel JM, Fairchok MP: Two cases of Lactobacillus bacteremia during probiotic treatment of short gut syndrome. J Pediatr Gastroenterol Nutr 2004;38:457-458.

23 Land MH, Rouster-Stevens K, Woods CR, Cannon ML, Cnota J, Shetty AK: Lactobacillus sepsis associated with probiotic therapy. Pediatrics 2005;115:178-181. 